\title{
PCR detection and PFGE DNA macrorestriction analyses of clinical isolates of Pseudomonas anguilliseptica from winter disease outbreaks in sea bream Sparus aurata
}

\author{
M. Mar Blanco, Alicia Gibello, Ana Isabel Vela, Miguel Angel Moreno, \\ Lucas Domínguez, José Francisco Fernández-Garayzábal*
}

Departmento Patología Animal I (Sanidad Animal), Facultad de Veterinaria, Universidad Complutense, 28040 Madrid, Spain

\begin{abstract}
A PCR-based detection system for Pseudomonas anguilliseptica was evaluated. The primer combination PAF-PAR (forward primer PAF = 5'-GACCTCGCCATTA-3', reverse primer PAR = 5'-CTCAGCAGTTTTGAAAG-3') gave a unique and specific amplification product of $439 \mathrm{bp}$ at an annealing temperature of $46^{\circ} \mathrm{C}$ with all the $P$. anguilliseptica isolates and strains $(\mathrm{n}=56)$ but no amplification products were observed with any other Pseudomonas species or phylogenetically related bacteria tested. The PCR assay had a detection limit of 170 to 200 cells per PCR tube, which was improved 8-fold when the PCR amplification product was used as a nonradioactive probe in blotting hybridization experiments. The PCR assay allowed the specific and reliable detection of $P$. anguilliseptica within $8 \mathrm{~h}$, compared with up to $10 \mathrm{~d}$ required for its isolation and further characterization by conventional microbiological approaches. Clinical isolates of $P$. anguilliseptica recovered from several winter disease (WD) outbreaks diagnosed in sea bream Sparus aurata in Spain and Portugal between 1996 and 2001 were characterized by pulse field-gel electrophoresis (PFGE) macrorestriction analysis. The 54 clinical isolates analyzed were included in 4 different pulsotypes. Pulsotypes B and C represented 54 and $25 \%$ of the isolates, respectively, and were responsible for most of the WD outbreaks diagnosed in Spain between 1996 and 2001. The implication of asymptomatic infected carriers in the dissemination and spread of WD is discussed.
\end{abstract}

KEY WORDS: Pseudomonas anguilliseptica $\cdot$ PCR detection $\cdot$ PFGE characterization $\cdot$ Winter disease Resale or republication not permitted without written consent of the publisher

\section{INTRODUCTION}

Pseudomonas anguilliseptica is an emerging fish pathogen that has gained clinical significance in being responsible for mortality outbreaks in different fish species. It was first isolated from cultured Japanese eels Anguilla japonica affected by red spot disease (Wakabayasi \& Egusa 1972). Subsequently it has been isolated from different fish species in several countries (Nakai \& Muroga 1982, Wiklund \& Bylund 1990, Lönnström et al. 1994, Wiklund \& Lönnström 1994, Berthe et al. 1995, Doménech et al. 1997, 1999, Al-

${ }^{*}$ Corresponding author. E-mail: garayzab@vet.ucm.es
Marzouk 1999, Haenen \& Davidse 2001). Recent microbiological studies have associated infection by $P$. anguilliseptica with the etiology of winter disease (WD) in sea bream Sparus aurata (Doménech et al. 1997, 1999). WD is a multifactorial syndrome associated with the nutritional and immune status of fish and stressful environmental conditions (Cinquina et al. 1998, Tort et al. 1998). It is characterized by a septicemic infection in which the most evident clinical signs are an abdominal distension because of the abundant ascitic fluid, pale liver, haemorrhagic kidney and congestive intestine with fibrinous yellowish exudate in the affected fish. During the past few years, several WD outbreaks in sea bream have been 
reported in different countries (Bovo et al. 1995, Doimi 1996, Doménech et al. 1997, 1999, Tort et al. 1998, Sarusic 1999). The severe mortality that can be observed during the WD outbreaks (Domenech et al. 1997), together with the fact that sea bream is one of the main marine non-salmonid fish species cultured (Caggiano 2000), make P. anguilliseptica a fish pathogen of emerging clinical significance.

The diagnosis of Pseudomonas anguilliseptica infections is made difficult by the slow growth rate and weak reactivity of this microorganism in most biochemical tests (Michel et al. 1992, Doménech et al. 1997, 1999). The detection and identification of fastidious microorganisms, like $P$. anguilliseptica, can be significantly improved by using molecular techniques. In this sense, PCR assays, based on primers designed to amplify variable regions of the $16 \mathrm{~S}$ rRNA gene, have been described for many bacterial fish pathogens (Martínez-Picado et al. 1994, Saulnier \& Kinkelin 1997. Urdaci et al. 1998, Zlotkin et al. 1998a, Gibello et al. 1999).

Despite the clinical and commercial significance of Pseudomonas anguilliseptica infections, there is a lack of information about the epidemiological relationships between strains of $P$. anguilliseptica isolated from different disease outbreaks, as well as the source of infection and the ways in which $P$. anguilliseptica is transmitted. For these purposes, DNA macrorestriction analysis by pulsed-field gel electrophoresis (PFGE) has proved to be a reliable and highly discriminatory technique that has been successfully applied to the molecular characterization of different fish pathogens (Hanninen \& Hirvela-Koski 1999, Vela et al. 2000).

The aim of this study was to develop a PCR-based detection system for Pseudomonas anguilliseptica, as well as to characterize, by PFGE DNA macrorestriction analysis, the $P$. anguilliseptica clinical isolates recovered from several WD outbreaks diagnosed in sea bream in Spain and Portugal between 1996 and 2001.

\section{MATERIALS AND METHODS}

Bacterial strains. The study included 54 clinical isolates of Pseudomonas anguilliseptica (Table 1) obtained from sea bream affected by WD in Spain and Portugal between 1996 and 2001. P. anguilliseptica isolates were isolated and identified as described previously (Doménech et al. 1997), and were frozen at $-80^{\circ} \mathrm{C}$ until further use. All clinical isolates were used for PCR and PFGE studies. Other Pseudomonas species and phylogenetically related taxa used for the specificity studies of the PCR assay are listed in Table 1.

Isolation of bacterial DNAs. Bacterial chromosomal DNA was extracted by the method of Lawson et al.
(1989). Purified DNA was dissolved in $50 \mu \mathrm{l}$ of distilled water and then stored at $-20^{\circ} \mathrm{C}$ until use.

Primer design and PCR amplification. The forward primer PAF (5'-GACCTCGCGCCATTA-3') and the reverse primer PAR (5'-CTCAGCAGTTTTGAAAG-3') were designed from non-conserved regions of the Pseudomonas anguilliseptica 16S rRNA gene sequence (Accession No. X99540) from Positions 202 to 216 and 624 to 640 , respectively, and were synthesized by ISOGEN (Bioscience BV). The apparent specificity of each oligonucleotide used as primer was determined according to Maidak et al. (1994). Primers were tested for PCR amplification at 2 different annealing temperatures $\left(43\right.$ and $46^{\circ} \mathrm{C}$ ), with DNA from selected strains of $P$. anguilliseptica, other Pseudomonas species and other taxa included in Table 1.

The PCR amplifications were performed in $100 \mu \mathrm{l}$ reaction volumes containing DNA template (50 to $70 \mathrm{ng}$ of chromosomal bacterial DNA, $20 \mu \mathrm{l}$ of boiled cells, or $10 \mu \mathrm{l}$ of DNA extracted from fish tissue, later subsection), $1 \mathrm{mM}$ of each primer (PAF and PAR), $2 \mathrm{mM}$ of each deoxynucleotide triphosphate, and $2.5 \mathrm{U}$ of Amplitaq gold DNA polymerase (PE Biosystems) in $1 \times$ reaction buffer. After an additional denaturation step of $95^{\circ} \mathrm{C}$ for $7 \mathrm{~min}$ and 35 cycles of $95^{\circ} \mathrm{C}$ for $1 \mathrm{~min}$, annealing at the selected temperature for $1 \mathrm{~min}$ and extension at $72^{\circ} \mathrm{C}$ for $1 \mathrm{~min} 30 \mathrm{~s}$ were performed, followed by a final extension step of $72^{\circ} \mathrm{C}$ for $5 \mathrm{~min}$. Negative (no template DNA) and positive (50 ng of purified DNA from Pseudomonas anguilliseptica Strain CECT 899) controls were included in each batch of PCR reactions. The amplifications were carried out in a PT-100 thermal cycler (MJ Research). PCR-generated products were detected by electrophoresis of $15 \mu \mathrm{l}$ of each amplification mixture in $1 \%$ agarose gels in $1 \%$ trisacetate-EDTA buffer. Gels were stained with $0.5 \mathrm{mg}$ $\mathrm{ml}^{-1}$ ethidium bromide.

Specificity and sensitivity of the PCR. The specificity of the PCR assay was tested by using, as template, the extracted DNA of all Pseudomonas strains and the clinical isolates obtained between 1996 and 1998 and other bacteria listed in Table 1. For screening the clinical isolates of $P$. anguilliseptica isolated between 1999 and 2001, 1 bacterial colony was suspended in $0.2 \mathrm{ml}$ of sterile water and boiled for $10 \mathrm{~min}$, and $20 \mu \mathrm{l}$ of this suspension was added directly to $80 \mu$ l of PCR mixture.

To determine the detection limit of the PCR, a suspension of Pseudomonas anguilliseptica Strain CECT 899 containing $1.3 \times 10^{6}$ cells $^{-1} \mathrm{ml}$ was serially diluted 2-fold in $0.9 \%$ saline buffer to $2.5 \times 10^{3}$ cells ml $^{-1}$. Twenty microliters of each dilution was boiled for $10 \mathrm{~min}$ and added directly to the PCR mixture. The bacterial concentration was determined by plating $0.1 \mathrm{ml}$ of each dilution onto MacConkey agar plates (bioMérieux España S.A.). 
Table 1. Bacterial species assayed in the PCR experiments. CECT: Colección Española de Cultivos Tipo (Spanish Type Culture Collection), Valencia, Spain

\begin{tabular}{|c|c|c|}
\hline Species & Strain & $\begin{array}{l}\text { Source and/or } \\
\text { geographic origin }\end{array}$ \\
\hline \multicolumn{3}{|l|}{ Pseudomonas spp. } \\
\hline Collection strains & CECT $899^{\mathrm{T}}$ & Japanese eel, Japan \\
\hline & СЕСТ 900 & European eel, Scotland \\
\hline \multirow{2}{*}{ Clinical isolates } & A/1168, A/1169 & Sea bream, Portugal \\
\hline & $\begin{array}{l}\mathrm{A} / 1123, \mathrm{~A} / 1203, \mathrm{~A} / 1204, \mathrm{~A} / 1379, \\
\mathrm{~A} / 1380, \mathrm{~A} / 1413-\mathrm{A} / 1419, \mathrm{~A} / 1442, \\
\mathrm{~A} / 1443, \mathrm{~A} / 1445, \mathrm{~A} / 1748-\mathrm{A} / 1754 \\
\mathrm{~A} / 1763-\mathrm{A} / 1766,99 / 4422,99 / 4472 \\
00 / 4854,00 / 4862,00 / 4891,00 / 4895 \\
00 / 4897,00 / 4900,00 / 4923,00 / 4964, \\
01 / 5237,01 / 5246,01 / 5254,01 / 5255 \\
01 / 5263,01 / 5296,01 / 5297,01 / 5305 \\
01 / 5311,01 / 5328,01 / 5330,01 / 5331, \\
01 / 5348,01 / 5357,01 / 5386,01 / 5421\end{array}$ & Sea bream, Spain \\
\hline \multirow[t]{3}{*}{ P. aeruginosa } & CECT $110^{\mathrm{T}}$ & \\
\hline & CECT 118 & Human, UK \\
\hline & CECT 4001 & Human clinical isolate, UK \\
\hline P. mendocina & CECT $320^{\mathrm{T}}$ & Soil, Argentina \\
\hline P. oleovorans & CECT $4079^{\mathrm{T}}$ & Industrial lubricant \\
\hline$P$. fluorescens & CECT $378^{\mathrm{T}}$ & Pre-filter water tanks, UK \\
\hline$P$. alcaligenes & CECT $929^{\mathrm{T}}$ & Swimming pool water \\
\hline P. putida & CECT $324^{\mathrm{T}}$ & Soil, USA \\
\hline P. stutzeri & CECT $930^{\mathrm{T}}$ & Human spinal fluid \\
\hline P. pseudoalcaligenes & CECT $318^{\mathrm{T}}$ & Human sinus discharge \\
\hline P. tolaasii & CECT $4472^{\mathrm{T}}$ & Diseased mushrooms, UK \\
\hline Pseudomonas sp. & S99/104 & Chinese softshell, Spain \\
\hline \multicolumn{3}{|l|}{ Other genera } \\
\hline Burkholderia cepacia & CECT 322 & Forest soil, Trinidad \\
\hline Burkholderia caryophylli & CECT 117 & D. caryophilus, Denmark \\
\hline Ralstonia picketti & CECT $330^{\mathrm{T}}$ & Human clinical isolate, USA \\
\hline Brevundimonas diminuta & CECT $317^{\mathrm{T}}$ & Fresh water stream, USA \\
\hline Comamonas acidovorans & CECT $311^{\mathrm{T}}$ & Soil, The Netherlands \\
\hline Serratia marcescens & CECT 846 & Pond water, Czech Republic \\
\hline
\end{tabular}

Preparation of homogenates of artificially contaminated sea bream tissue. Samples of liver, kidney and spleen from 25 sea bream were obtained aseptically. These organs were weighed and blended with the appropiate volume of $0.9 \%$ saline buffer to obtain a 1/10 dilution of each organ. The absence of Pseudomonas anguilliseptica in the tissue homogenates was determined by plating $0.1 \mathrm{ml}$ onto MacConkey agar plates which were incubated at $22^{\circ} \mathrm{C}$ for $7 \mathrm{~d}$. Samples (1 ml) of tissue homogenate were inoculated with $P$. anguilliseptica CECT 899 to obtain a final concentration of $8 \times 10^{6}$ bacteria $\mathrm{g}^{-1}$. The enumeration of $P$. anguilliseptica in the contaminated tissues was determined by plating $0.1 \mathrm{ml}$ of appropriate 10 -fold dilutions of these homogenates onto MacConkey agar plates incubated for $7 \mathrm{~d}$ at $22^{\circ} \mathrm{C}$. Non-inoculated tissue homogenates were used as controls.
DNA extraction from tissues. Two different methods were evaluated for the DNA extraction from tissue homogenates: the method described by Lawson et al. (1989), which includes the use of phenol/chloroform (PhC method), and the technique described by Casas et al. (1995), which involves a single extraction using a guanidinium thiocyanate acid buffer (GuSCN method). Fifty microlitres of tissue homogenate were processed by both methods. The total extracted DNA was dissolved in $10 \mu \mathrm{l}$ of sterile distilled water and used for PCR experiments.

Slot blot hybridization. Two hundred microlitres of Pseudomonas anguilliseptica suspensions containing $3 \times 10^{8}$ to $3 \times 10^{0}$ cells ml $^{-1}$ were transferred to a nylon membrane (Roche Laboratories) by a slot blot procedure using a Bio-Dot microfiltration apparatus (BioRad). Bacterial DNA was extracted by alkaline lysis as 
described by Sambrook et al. (1989) and DNA was fixed to the membrane by UV crosslinker in a Spectrolinker XL-1000 (Spectronic Corporation). Then, the blot was assayed against the $439 \mathrm{bp}$ biotin-labelled product obtained from the strain $P$. anguilliseptica CECT 899 DNA PCR amplification, with the biotin primers PAF and PAR labelled at the 5'-end. Prehybridization and hybridization were performed at $65^{\circ} \mathrm{C}$ for $3 \mathrm{~h}$ in a solution of $5 \times \mathrm{SSC}(1 \times \mathrm{SSC}$ is $0.15 \mathrm{M} \mathrm{NaCl}$ plus $0.015 \mathrm{M}$ sodium citrate) and $0.1 \%$ sodium dodecyl sulfate (SDS). The labelled probe was used at a concentration of $20 \mathrm{ng} \mathrm{ml}^{-1}$. Washes under high-stringency conditions and hybridized DNA detection using CDP-Star procedure (Roche Molecular Biochemicals) were carried out as previously described (Gibello et al. 1999).

PFGE. Pseudomonas anguilliseptica strains were grown on Columbia blood agar plates at $22^{\circ} \mathrm{C}$ for $5 \mathrm{~d}$. Cells were harvested with a loop and resuspended in $2 \mathrm{ml}$ of SE buffer (75 mM NaCl, 25 mM EDTA, pH 7.5), to obtain a final absorbance of 0.6 at $600 \mathrm{~nm}$. Cells were harvested by centrifugation at $3500 \mathrm{rpm}$ for $10 \mathrm{~min}(821 \times g)$ at $4^{\circ} \mathrm{C}$, washed twice with $2 \mathrm{ml}$ of SE buffer, and resuspended in $3 \mathrm{ml}$ of SE buffer. The cell suspension was mixed with an equal volume of $2 \%$ $(\mathrm{w} / \mathrm{v})$ low-melting-point agarose. When solidified, blocks were incubated in lysis buffer $(50 \mathrm{mM}$ Tris- $\mathrm{HCl}$, $50 \mathrm{mM}$ EDTA and $1 \% \mathrm{n}$-lauroyl-sarcosine sodium salt

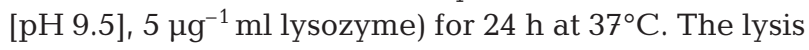
buffer was replaced with $2 \mathrm{ml}$ lysis buffer containing $2.5 \mu^{-1} \mathrm{ml}$ of Proteinase $\mathrm{K}$, and the blocks were incubated at $56^{\circ} \mathrm{C}$ for $48 \mathrm{~h}$. Blocks were washed 3 times with tris-EDTA buffer for $1 \mathrm{~h}$ at $4^{\circ} \mathrm{C}$. SpeI and XbaI (Promega), were used for restriction endonuclease digestion according to the manufacturer's instructions. Spe I and Xba I have been previously used in PFGE analysis of $P$. aeruginosa (Hla et al. 1996, Speijer et al. 1999). DNA fragments were resolved by pulsed fieldgel electrophoresis (PFGE) using a CHEF-DR III System (Bio-Rad Laboratories). Electrophoresis of digested samples was performed through $1 \%(\mathrm{w} / \mathrm{v})$ electrophoresis-grade agarose (Roche Molecular Biochemicals) under the following conditions: running time $19 \mathrm{~h}$, temperature $14^{\circ} \mathrm{C}$, voltage gradient $200 \mathrm{~V}$, initial pulse time $0.1 \mathrm{~s}$, final pulse time, $15 \mathrm{~s}$, included angle $120^{\circ}$. Gels were stained with $0.5 \mathrm{mg}$ of ethidium bromide $\mathrm{l}^{-1}$ and DNA was visualized by UV transillumination. Lambda ladder PFGE Marker 1 (Boehringer Mannheim, Roche) was used for molecular weight size determination.

Macrorestriction patterns were analyzed both visually and by computer-aided methods. The visual genetic relationship among isolates was evaluated following the criteria of Tenover et al. (1995). PFGE patterns that differed by more than 3 bands were recorded as types and are identified with a capital letter. Patterns that differed by 1 to 3 bands were recorded as different subtypes and are identified with a capital letter followed by an arabic numeral. The similarities between restriction endonuclease digestion profiles were expressed as the Jaccard similarity index with a TAXAN program and cluster analysis by the unweighted pair group method using arithmetic averages.

\section{RESULTS AND DISCUSSION}

\section{PCR assay}

The primer combination PAF-PAR gave a unique and specific amplification product of $439 \mathrm{bp}$ length at an annealing temperature of $46^{\circ} \mathrm{C}$ with Pseudomonas anguilliseptica isolates only. At an annealing temperature of $43^{\circ} \mathrm{C}$, amplification products were observed with $P$. fluorescens and $P$. aeruginosa (data not shown). Identical amplification products were obtained when the PCR was performed with whole bacterial cells boiled for $10 \mathrm{~min}$ instead of extracted DNA. The annealing temperature of $46^{\circ} \mathrm{C}$ was used for all subsequent PCR assays. All clinical P. anguilliseptica isolates had a $439 \mathrm{bp}$ amplification product, but no amplification products were observed with any of the other Pseudomonas species or phylogenetically related bacteria listed in Table 1 (Fig. 1). Therefore, the primer combination PAF and PAR at this annealing temperature proved to be specific for $P$. anguilliseptica. The PCR assay had a detection limit of $1 \times 10^{4}$ cells ml- ${ }^{-1}$, which equates to 200 cells per PCR reaction mixture (Fig. 2), assuming that the lysis procedure was complete (no viable cells were detected after the boiling treatment). The level of detection increased 8-fold, when the PCR amplification product was used as a nonradioactive probe in blotting hybridization experiments, where the minimum amount of $P$. anguilliseptica detected was 24 bacterial cells (data not shown).

Initial experiments with artificially contaminated tissue homogenates of 5 sea bream showed that the observed yield of the PCR products was greater with the GuSCN DNA extraction method than with the PhC method (data not shown). In addition, the former procedure was less time-consuming ( $1 \mathrm{~h})$ compared with the $4 \mathrm{~h}$ needed for the $\mathrm{PhC}$ method. This result indicated that, as previously reported for viral DNA (Casas et al. 1995), the GuSCN method is also a simple, reliable and useful procedure for Pseudomonas anguilliseptica DNA extraction from tissues. Thus, the GuSCN method was further routinely used for DNA extraction from the homogenates of artificially contaminated sea bream tissue. 


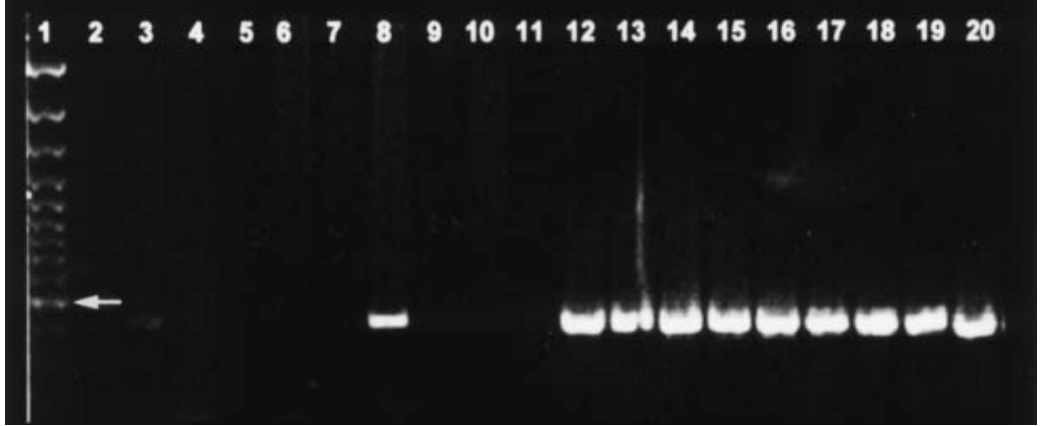

Fig. 1. Specificity of the PCR assay Pseudomonas anguilliseptica: ethidiumbromide-stained gel with the specific amplification product of $439 \mathrm{bp}$ obtained by extracted DNA PCR at $46^{\circ} \mathrm{C}$ annealing temperature with primers PAF-PAR from different bacterial species. Lane 1: Gene Ruler 100 bp DNA ladder plus (MBI Fermentas) (arrow indicates $500 \mathrm{bp}$ marker); Lane 2: negative control; Lane 3: Pseudomonas anguilliseptica CECT 900; Lanes 4 to 7: P. aeruginosa CECT $110^{\mathrm{T}}$, P. fluorescens CECT $378^{\mathrm{T}}$, P. putida CECT $324^{\mathrm{T}}$ and P. pseudoalcaligenes CECT $318^{\mathrm{T}}$, respectively; Lane 8: Pseudomonas anguilliseptica CECT $899^{\mathrm{T}}$; Lanes 9 to 11 : Burkholderia cepacia CECT 322, Ralstonia picketti CECT $330^{\mathrm{T}}$, and Serratia marcescens CECT 846, respectively; Lanes 12 to 17: Pseudomonas anguilliseptica A-1123, A-1765, 99/4422, 00/4862, 00/4900, and 01/5246, respectively; Lanes 18 to 20: spleen, liver, and kidney tissue homogenates, artificially contaminated with Pseudomonas anguilliseptica CECT 899, respectively

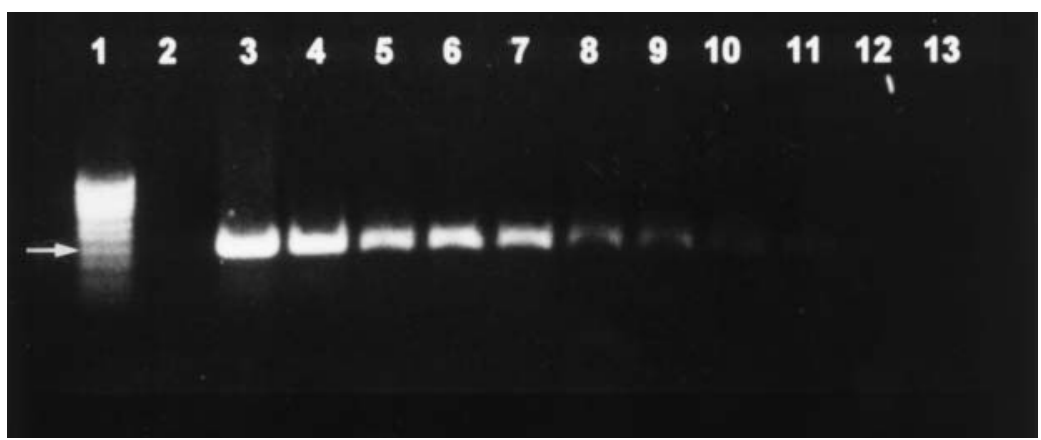

Fig. 2. Pseudomonas anguilliseptica. Sensitivity of detection by PCR. Lane 1: $1000 \mathrm{bp}$ ladder (Biotools) (arrow indicates $400 \mathrm{bp}$ marker); Lane 2: negative control; Lane 3: Pseudomonas anguilliseptica CECT 899 ${ }^{\mathrm{T}}$; Lanes 4 to 13: 2-fold decreasing boiled cell concentrations ranging from $2.6 \times 10^{4}$ to 50 per PCR reaction mixture, respectively

assays (Coleman et al. 1996, McIntosh et al. 1996), the sensitivity of the PCR assay with tissue extracts was very similar to that obtained with cell suspensions. The absence of inhibitory effects may be due to the 10 -fold dilution step of the tissues (Gibello et al. 1999) and/or the DNA extraction procedure used, which would reduce or eliminate the possible inhibitory substances present in the tissue extracts (Altinok et al 2001).

Pseudomonas anguilliseptica is a very slow growing organism that is difficult to identify by standard biochemical tests due to its slow reactive metabolism (Doménech et al. 1997). Hence, the PCR assay developed here allows the specific and reliable detection of $P$. anguilliseptica within $8 \mathrm{~h}$ of receiving a sample compared with up to $10 \mathrm{~d}$ required for its isolation and further identification by conventional microbiological approaches (Doménech et al. 1997). The data presented here point out the efficacy of the PCR assay developed for a rapid and accurate identification of $P$. anguilliseptica.

The detection limit using artificially contaminated tissue homogenates of the PCR assay was lower than the bacterial counts that Pseudomonas anguilliseptica can reach in target organs of experimentally infected fish (Haenen \& Davidse 2001). Thus, it is likely that the PCR assay could be also useful for the rapid and specific diagnosis of natural infections by $P$. anguilliseptica, including WD.

\section{PFGE analysis}

When the PCR assay was used for the detection of Pseudomonas anguilliseptica in experimentally inoculated tissues, the $439 \mathrm{bp}$ amplification product was detected from all tissue homogenates (Fig. 1, Lanes 18 to 20), regardless of the type of tissue. The detection limit of the PCR assay in tissues was 170 cells per reaction mixture, which equates to $3.4 \times 10^{4}$ cells $\mathrm{g}^{-1}$ tissue (data not shown). This detection limit is similar to those described in PCR assays with other bacterial fish pathogens (McIntosh et al. 1996, Urdaci et al. 1998, Gibello et al. 1999). Although the presence of host DNA or inhibitory substances in tissue extracts has been reported to reduce the sensitivity of the PCR
PFGE of Pseudomonas anguilliseptica chromosomal DNA digested with $X b a I$ yielded 13 to 16 fragments in the 48 to $194 \mathrm{~kb}$ size range, while SpeI digested DNA yielded patterns of 20 to 25 fragments of 30 to $291 \mathrm{~kb}$ (Fig. 3). The PFGE patterns of the same isolate generated for each of the 2 restriction endonucleases were found to be stable and reproducible in at least 3 separate trials on different gels. With the $X b a I$ digestion, 2 restriction patterns were identified through visual comparison of gels. One restriction pattern included 46 clinical isolates, the remaining isolates $(01 / 5255,01 / 5263,01 / 5297,01 / 5305,01 / 5311$, 


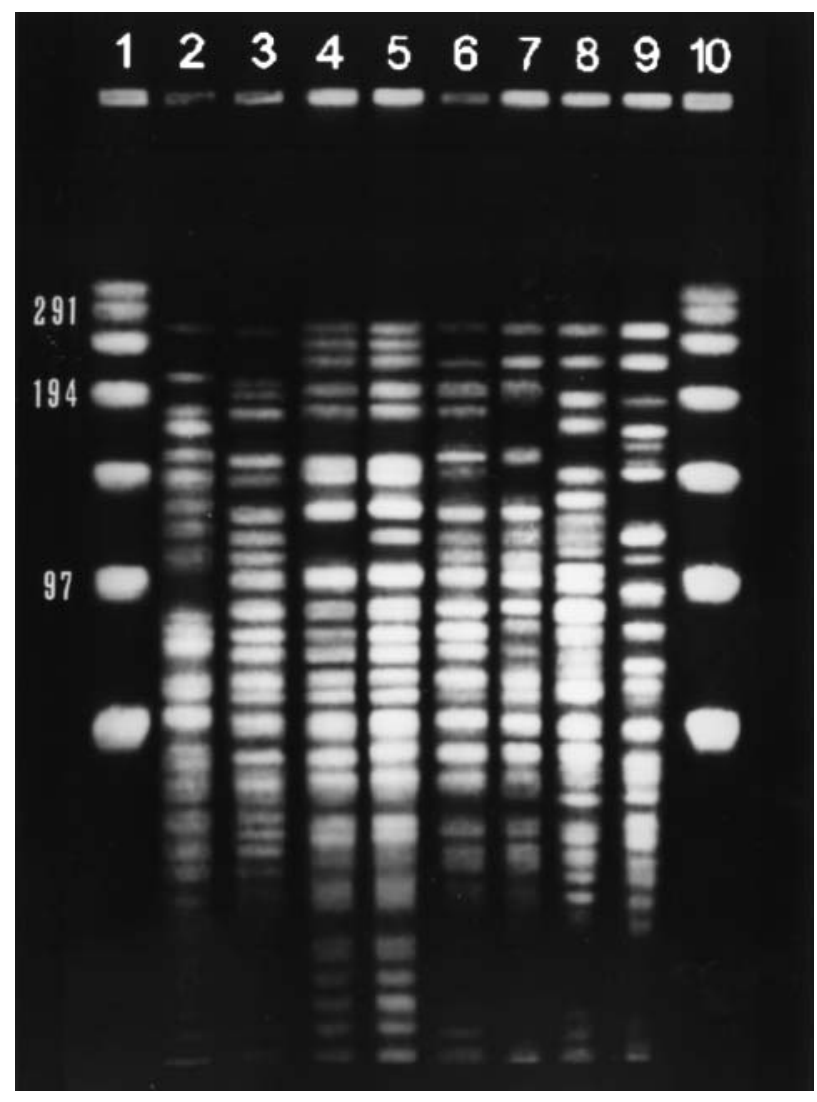

Fig. 3. Pseudomonas anguilliseptica. Pulsed-field gel electrophoresis patterns (PFGE) of SpeI digested DNA of clinical isolates. Lanes 1 and 10: Roche molecular weight marker (48.5 to $1000 \mathrm{kbp);} \mathrm{Lane} \mathrm{2:} \mathrm{Pulsotype} \mathrm{F} \mathrm{(Strain} \mathrm{CECT} \mathrm{900);}$ Lane 3: Pulsotype B (Isolate A/1380); Lane 4: Pulsotype D2 (Isolate A/1168); Lane 5: Pulsotype D1 (Isolate A/1123); Lane 6: Pulsotype C1 (Isolate 99/4422); Lane 7: Pulsotype C2 (Isolate 01/5254); Lane 8: Pulsotype E (Isolate 01/5263); Lane 9: Pulsotype A (Strain CECT 899)
01/5328, 01/5331 and 01/5357) displayed indistinguible restriction patterns with a genetic similarity of $70 \%$ with the predominant clone (data not shown). The SpeI enzyme was found to be more discriminatory than $\mathrm{XbaI}$. The 46 clinical isolates that were indistinguishable with $\mathrm{XbaI}$ digestion were distributed in 3 pulsotypes, identified as B, C and D after SpeI digestion (Fig. 4, Table 2). Most of the isolates $(53.8 \%)$ were included in Pulsotype B. Pulsotype C ( $25 \%$ of the strains) was discriminated by PFGE band analysis into 2 subtypes with more than $85 \%$ similarity; Subtype C1 was the most prevalent (11 isolates). Pulsotype D (9.6\% of the isolates) included a majority subtype, Subtype D1, with most of the clinical isolates from the first outbreaks of WD detected in 1996 in Spain (Doménech et al. 1997), and Subtype D2, with only the Strain A/1168. The levels of similarity of Pulsotypes C and D to Pulsotype B according to the Jaccard coefficient were 75 and $55 \%$, respectively. The isolates 01/5255, 01/5263, 01/5297, 01/5305, 01/5311, 01/5328, 01/5331 and 01/5357 displayed a different restriction pattern (Pulsotype E) (Fig. 4, Table 2). The Collection Strains $P$. anguilliseptica CECT 899 and CECT 900 displayed different restriction profiles, designated Pulsotypes A and $\mathrm{F}$, respectively.

Pseudomonas anguilliseptica has been isolated from different farmed fish species in different countries (Wiklund \& Bylund 1990, Berthe et al. 1995, Al-Marzouk 1999, Haenen et al. 2001), suggesting a widespread distribution of this microorganism. Although there are no previously reported molecular characterization studies about the genetic and epidemiological relationships of its clinical isolates, $P$. anguilliseptica could be expected to have, like some other widely distributed microorganisms (Chomarat et al. 1998, Hanninen \& HirvelaKoski 1999), a great genetic heterogeneity. However, the clinical isolates of $P$. anguilliseptica studied, with only 4 different pulsotypes, displayed low genetic diversity. This result could be related to the fact that 52 of the 54 isolates examined were recovered from the same host fish species affected by WD, and a somewhat limited geographic area. Pulsotypes $\mathrm{B}$ and $\mathrm{C}$ were responsible for

Fig. 4. Pseudomonas anguilliseptica. Dendogram of isolates based on UPGMA cluster analysis of the 6 different pulsotypes observed in this study following SpeI endonuclease DNA digestion 
Table 2. Pulsotype characterization of the Pseudomonas anguilliseptica isolates by PFGE obtained after DNA digestion with the Spe I restriction enzyme. CAT: Cataluña (north-east Spain); LEV: Levante (east Spain); AND: Andalucía (south Spain); LIS SET: Lisboa and Setubal, respectively (southwest Portugal). The different numbers follwing the same geographic origin indicate different fish farms

\begin{tabular}{|c|c|c|c|}
\hline Pulsotype & Isolate(s) & $\begin{array}{c}\text { Year } \\
\text { of isolation }\end{array}$ & $\begin{array}{l}\text { Geographic } \\
\text { location of } \\
\text { fish farm }\end{array}$ \\
\hline $\mathrm{A}$ & CECT 899 ${ }^{\mathrm{T}}$ & 1972 & Collection strain \\
\hline B & $\begin{array}{l}\text { A/1379, A/1380 } \\
\text { A/1413-A/1418 } \\
\text { A/1419 } \\
\text { A/1442, A/1443 } \\
\text { A/1748-A/1754 } \\
\text { A/1763-A/1766 } \\
99 / 4472 \\
00 / 4897 \\
00 / 4900 \\
00 / 4923 \\
01 / 5237 \\
01 / 5296\end{array}$ & $\begin{array}{l}1996 \\
1997 \\
1997 \\
1997 \\
1997 \\
1998 \\
1999 \\
2000 \\
2000 \\
2000 \\
2001 \\
2001\end{array}$ & $\begin{array}{l}\text { CAT-2 } \\
\text { LEV-1 } \\
\text { LEV-2 } \\
\text { CAT-2 } \\
\text { CAT-5 } \\
\text { CAT-2 } \\
\text { CAT-2 } \\
\text { CAT-5 } \\
\text { LEV-2 } \\
\text { CAT-2 } \\
\text { CAT-2 } \\
\text { LEV-2 }\end{array}$ \\
\hline $\mathrm{C} 1$ & $\begin{array}{l}\mathrm{A} / 1445 \\
99 / 4422 \\
00 / 4854,00 / 4862 \\
00 / 4891,00 / 4964 \\
00 / 4895 \\
01 / 5246,01 / 5421 \\
01 / 5330 \\
01 / 5386\end{array}$ & $\begin{array}{l}1997 \\
1999 \\
2000 \\
2000 \\
2000 \\
2001 \\
2001 \\
2001\end{array}$ & $\begin{array}{l}\text { CAT-4 } \\
\text { CAT-4 } \\
\text { AND-2 } \\
\text { CAT-3 } \\
\text { CAT-4 } \\
\text { CAT-4 } \\
\text { LEV-3 } \\
\text { LEV-2 }\end{array}$ \\
\hline $\mathrm{C} 2$ & $\begin{array}{l}01 / 5254 \\
01 / 5348\end{array}$ & $\begin{array}{l}2001 \\
2001\end{array}$ & $\begin{array}{l}\text { CAT-6 } \\
\text { CAT-9 }\end{array}$ \\
\hline D1 & $\begin{array}{l}\text { A/1123 } \\
\text { A/1169 } \\
\text { A/1203, A/1204 }\end{array}$ & $\begin{array}{l}1996 \\
1996 \\
1996\end{array}$ & $\begin{array}{l}\text { AND-1 } \\
\text { SET } \\
\text { CAT-1 }\end{array}$ \\
\hline D2 & $\mathrm{A} / 1168$ & 1996 & LIS \\
\hline E & $\begin{array}{l}01 / 5255 \\
01 / 5263 \\
01 / 5297,01 / 5305 \\
01 / 531101 / 5328 \\
01 / 5331,01 / 5357\end{array}$ & $\begin{array}{l}2001 \\
2001 \\
2001 \\
\\
2001\end{array}$ & $\begin{array}{l}\text { CAT-8 } \\
\text { CAT-7 } \\
\text { CAT-4 } \\
\text { CAT-3 }\end{array}$ \\
\hline $\mathrm{F}$ & CECT 900 & 1981 & Collection strain \\
\hline
\end{tabular}

most of the WD outbreaks studied by us in Spain between 1996 and 2001, which is in agreement with the existence of prevalent clones responsible for a great majority of the clinical cases observed in other fish pathogens (Vela et al. 2000). Experimental pathogenicity studies have suggested that certain strains of $P$. anguilliseptica would be more pathogenic for certain fish species (Haenen \& Davidse 2001). Therefore, although the pathogenicity of Pulsotypes B and C was not evaluated, their isolation from most of the WD outbreaks diagnosed by us may be related to a higher pathogenic potential of these pulsotypes for sea bream. In addition, their rapid spread in different geographical areas (Table 2), and their isolation in the same year from fish farms located several hundred kilometers apart, suggest that $P$. anguilliseptica is actually widespread but has only recently emerged as a pathogen as the industry has expanded or environmental conditions have promoted its emergence. The movement of infected fish/asymptomatic carriers into susceptible populations through the trade of livestock is one of the main factors responsible for the dissemination and transmission of fish pathogens (Lönnström et al. 1994, Hanninen \& Hirvela-Koski 1999). P. anguilliseptica (Pulsotype B) was isolated from asymptomatic sea breams surviving a natural infection, suggesting the existence of a carrier state (A. Rodríguez unpubl. data). Also, the Portuguese sea bream affected by WD in 1996 were imported from Andalucía about 9 mo before the onset of the outbreak, and $P$. anguilliseptica Strains A-1123 and A-1169, with the same Pulsotype D (Subtype D1) was isolated from both Portuguese and Spanish fish farms (Fig. 3, Table 2). These results suggest that asymptomatic carriers may play an important role in the spread of WD between fish farms. This could also be the reason for the detection of Pulsotype E in 4 out of the 8 fish farms with WD outbreaks during 2001. The repeated isolation of Pulsotypes B and C from the same fish farm during several consecutive years (Table 2), indicates that $P$. anguilliseptica is able to persist over time in the same fish farm, which could be related either with the presence of asymptomatic carriers which could act as reservoirs of $P$. anguilliseptica between WD outbreaks, or alternatively with the ability of this microorganism to survive in the water environment (Muroga et al. 1977). Wild fish can be potential reservoirs of bacterial fish pathogens for cultured fish species (Zlotkin et al. 1998b). Moreover, the potential implication of wild fish as reservoirs of $P$. anguilliseptica (Lönnström et al. 1994) for cultured sea bream cannot be ruled out. Regardless of the source of $P$. anguilliseptica, farmed sea bream populations would develop WD under predisposing stressful conditions (Cinquina et al. 1998, Tort et al. 1998).

Our data show that PFGE analysis is a reliable and reproducible molecular technique for discriminating between isolates of Pseudomonas anguilliseptica and should facilitate epidemiological studies of this fish pathogen. Clinical isolates of some bacterial fish pathogens isolated from different geographic origins belong to different clones (Skov et al. 1995, Lucangeli et al. 2000, Vela et al. 2000). Although this study provides significant information about the genetic and epidemiological relationship of the $P$. anguilliseptica clinical isolates from WD outbreaks in sea bream in Spain, similar studies should be conducted with clinical isolates from other countries and susceptible fish species for a better understanding of the epizootiology of $P$. anguilliseptica infections. 
Acknowledgements. This work was funded by project ACU00-004-C2-2 from the Spanish Ministry of Ciencia y Tecnología, and Dibaq-Diproteg S.A. The authors thank M. T. Cutuli, A. Doménech, J. A. García, P. Liébana, C. Albendea and F. Padrós for isolating and providing the Pseudomonas anguilliseptica Spanish clinical isolates. We thank F. Uruburu (Director of the Spanish Type Culture Collection) for providing the collection strains. The help of A. Casamayor in the PFGE experiments is also gratefully acknowledged. M.M.B. and A.G. contributed equally to this work.

\section{LITERATURE CITED}

Al-Marzouk AE (1999) Association of Pseudomonas anguilliseptica with mortalities in cultured marine orangespotted grouper Epinephelus coioides in Kuwait. Fish Pathol 34:167-168

Altinok I, Grizzle JM, Zhanjiang L (2001) Detection of Yersinia ruckeri in rainbow trout blood by use of the polymerase chain reaction. Dis Aquat Org 44:29-34

Berthe FCJ, Michel C, Bernardet (JF) (1995) Identification of Pseudomonas anguilliseptica isolated form several fish species in France. Dis Aquat Org 21:151-155

Bovo G, Borghesan F, Comuzzi M, Ceschia G, Giorgetti G (1995) Winter disease in orata di allevamento:osservazioni preliminari. Boll Soc It Patol Ittica 17:2-11

Caggiano M (2000) Quality in harvesting and post-harvesting procedures-influence on quality. Fish freshness and quality assessment for sea bass and sea bream. Cah Options Méditerr 51: 55-61

Casas I, Powell L, Klapper PE, Cleator GM (1995) New method for the extraction of viral RNA and DNA from cerebrospinal fluid for use in the polymerase chain reaction assay. J Virol Methods 53:25-36

Chomarat M, Guérin-Faublée V, Kodjo A, Breysse F, Flandrois JP (1998) Molecular analysis of the fish pathogen Aeromonas salmonicida subsp. salmonicida by pulsed field gel electrophoresis. Rev Méd Vét 149/3:245-250

Cinquina A, Raponi A, Barchi D, Cozzani R, Gennari L, di Giambernardino F, Bilei S (1998) Residui di flumequine in orate. Ricerche in corso di winter disease. Obiettivi Documenti Vet 10:57-62

Coleman SS, Melanson DM, Biosca EG, Oliver JD (1996) Detection of Vibrio vulnificus biotypes 1 and 2 in eels and oysters by PCR amplification. Appl Environ Microbiol 62:1378-1382

Doimi M (1996) A new winter disease in sea bream (Sparus aurata): a preliminary report. Bull Eur Assoc Fish Pathol $16: 17-18$

Doménech A, Fernández-Garayzábal JF, Lawson P, García JA and 6 others (1997) Winter disease outbreak in sea-bream (Sparus aurata) associated with Pseudomonas anguilliseptica infection. Aquaculture. 156:317-326

Doménech A, Fernández-Garayzábal JF, García JA, Cutuli MT, Blanco M, Gibello A, Moreno MA, Domínguez L (1999) Association of Pseudomonas anguilliseptica infection with winter disease in sea bream, Sparus aurata L. J Fish Dis 22:69-71

Gibello A, Blanco MM, Moreno MA, Cutuli MT, Doménech A, Domínguez L, Fernández-Garayzábal JF (1999) Development of a PCR assay for detection of Yersinia ruckeri in tissues of inoculated and naturally infected trout. Appl Environ Microbiol 65:346-350

Haenen OLM, Davidse A (2001) First isolation and pathogenicity studies with Pseudomonas anguilliseptica from diseased European eel Anguilla anguilla (L.) in the
Netherlands. Aquaculture 196:27-36

Hanninen ML, Hirvela-Koski V (1999) Genetic diversity of atypical Aeromonas salmonicida studied by pulsed-field gel electrophoresis. Epidemiol Infect 123:299-307

Hla SW, Hui KP, Tan WC, Ho B (1996) Genome macrorestriction analysis of sequential Pseudomonas aeruginosa isolates from bronchiectasis patients without cystic fibrosis. J Clin Microbiol 34:575-578

Lawson PA, Gharbia SE, Shah HN, Clark DR (1989) Recognition of Fusobacterium nucleatum subgroups Fn-1, Fn-2 and Fn-3 ribosomal RNA gene restriction patterns. FEMS Microbiol Lett 65:41-46

Lönnström L, Wiklund T, Bylund G (1994) Pseudomonas anguilliseptica isolated from Baltic herring Clupea harengus membras with eye lesions. Dis Aquat Org 18: 143-147

Lucangeli C, Morabito C, Caprioli A, Achene L, Busani L, Mazzolini E, Fabris A, Macrì A (2000) Molecular fingerprinting of strains of Yersinia ruckeri serovar O1 and Photobacterium damsela subsp. piscicida isolated in Italy. Vet Microbiol. 76:273-281

Maidak BL, Larsen N, McCaughey MJ, Overbeek R, Olsen GJ, Fogel K, Blandy J, Woese CR (1994) The ribosomal database project. Nucleic Acids Res 22:3485-3487

Martínez-Picado J, Blanch AR, Jofre J (1994) Rapid detection and identification of Vibrio anguillarum by using a specific oligonucleotide probe complementary to 16S rRNA. Appl Environ Microbiol 60:1681-1683

McIntosh D, Meaden PG, Austin B (1996) A simplified PCRbased method for the detection of Renibacterium salmoninarum utilizing preparations of rainbow trout (Oncorhynchus mykiss, Walbaum) lymphocytes. Appl Environ Microbiol 62:3929-3932

Michel C, Bernardet JF, Dinand D (1992) Phenotypic and genotypic studies of Pseudomonas anguilliseptica strains isolated from farmed European eels (Anguilla anguilla) in France. Fish Pathol 27:229-232

Muroga K, Nakai T, Sawada T (1977) Studies on red spot disease of pond-cultured eels IV. Physiological characteristics of the causative bacterium, Pseudomonas anguilliseptica. Fish Pathol 12:33-38

Nakai T, Muroga K (1982) Pseudomonas anguilliseptica isolated from European eels (Anguilla anguilla) in Scotland. Fish Pathol 17:147-156

Sambrook J, Fritsch E, Maniatis T (1989) Molecular cloning: a laboratory manual, 2nd edn. Cold Spring Harbor Laboratory, Cold Spring Harbor, NY, p 1.98-1.99

Sarusic G (1999) Clinical signs of the winter disease phenomenon in sea bream (Sparus aurata, L.). Bull Eur Assoc Fish Pathol 19:113

Saulnier D, de Kinkelin P (1997) Polymerase chain reaction primers for investigations on the causative agent of proliferative kidney disease of salmonids. J Fish Dis 20: 467-470

Skov MA, Pedersen K, Larsen JL (1995) Comparison of pulsed-field gel electrophoresis, ribotyping, and plasmid profiling for typing of Vibrio anguillarum serovar O1. Appl Environ Microbiol 61:1540-1545

Speijer H, Savelkoul PHM, Bonten MJ, Stobberingh EE, Tjhie JHT (1999) Application of different genotyping methods for Pseudomonas aeruginosa in a setting of endemicity in an intensive care unit. J Clin Microbiol 37:3654-3661

Tenover FC, Arbeit RD, Goering RV, Mickelsen PA, Murray BE, Persing DH, Swaminathan B (1995) Interpreting chromosomal DNA restriction patterns produced by pulsedfield gel electrophoresis: criteria for bacterial strain typing. J Clin Microbiol 33:2233-2239 
Tort L, Padrós F, Rotllant J, Crespo S (1998) Winter syndrome in the gilthead sea bream Sparus aurata. Immunological and histopathological features. Fish Shellfish Immunol 8:37-47

Urdaci MC, Chakroun C, Faure D, Bernardet JF (1998) Development of a polymerase chain reaction assay for identification and detection of the fish pathogen Flavobacterium psychrophilum. Res Microbiol 149:519-530

Vela AI, Vázquez J, Gibello A, Blanco MM and 7 others (2000) Phenotypic and genetic characterization of Lactococcus garvieae isolated in Spain from lactococcosis outbreaks and comparison with isolates of other countries and sources. J Clin Microbiol 38:3791-3795

Wakabayasi H, Egusa S (1972) Characteristics of a Pseudo-

Editorial responsibility: Carey Cunningham,

Aberdeen, Scotland, UK monas sp. from an epizootic of pond-cultured eels (Anguilla japonica). Bull Jpn Soc Sci Fish 38:577-587

Wiklund T, Bylund G (1990) Pseudomonas anguilliseptica as a pathogen of salmonid fish in Finland. Dis Aquat Org 8:13-19

Wiklund T, Lönnström L (1994) Occurrence of Pseudomonas anguilliseptica in Finnish fish farms during 1986-1991. Aquaculture 126:211-217

Zlotkin A, Eldar A, Ghittino C, Bercovier H (1998a) Identification of Lactococcus garvieae by PCR. J Clin Microbiol 36:983-985

Zlotkin A, Hershko H, Eldar A (1998b) Possible transmission of Streptococcus iniae from wild fish to cultured marine fish. Appl Environ Microbiol26 64:4065-4067

Submitted: November 29, 2001; Accepted: February 15, 2002 Proofs received from author(s): June 17, 2002 